\title{
СТОМАТОАОГIЯ
}

https://doi.org/10.35339/msz.2019.82.01.12

УДК 616.314-76

\author{
В.П. Неспрядько, С.С. Терехов
}

Національний медичний університет імені О.О. Богомольця, м. Киӥв

\section{ВПЛИВ РЕТРАКЦІЇ НА МІКРОЦИРКУЛЯТОРНЕ РУСЛО У ТКАНИНАХ КРАЙОВОГО ПАРОДОНТА ПЕРЕД ОТРИМАННЯМ ВІДБИТКА ДЛЯ НЕЗНІМНИХ КОНСТРУКЦІЙ}

У статті розглядається вплив ретракції на мікроциркуляторне русло у тканинах крайового пародонта в пацієнтів із різними біотипами ясен. Відмічається взаємозв'язок між силою травмуючого агента під час ретракції ясен і фенотипом крайового пародонта.

Ключові слова: мікроциркуляторне русло, ретракція ясен, незнімні конструкції, відбитки, допплерівська флоуметрія.

\section{Вступ}

У 1961 році А. Javan було створено гелійнеоновий випромінювач, що започаткувало використання лазерів у медицині. Низькоінтенсивні випромінювачі даного типу почали застосовувати у фізіотерапії. У 1964 році було сконструйовано лазер на основі діоксиду вуглецю, що поклало початок хірургічному використанню лазерів.

У дослідженнях відмічають важливу роль оцінювання змін гемодинамічних ритмів тканинного кровотоку. Найбільш об'єктивно відображають стан тканинних систем пародонта дані лазерної допплерівської флоуметрії [1-4]. Даний метод полягає в тому, що тканини організму в оптичному плані можуть бути охарактеризовані як каламутні середовища [5-7]. Відображення лазерного випромінювання від рухомих у мікросудинах еритроцитів приводить до зміни частоти сигналу (ефект Допплера), що дозволяє визначити інтенсивність мікроциркуляції в досліджуваній ділянці тіла. Зворотне розсіювання монохроматичного зондуючого сигналу формується в результаті багаторазового розсіювання на поверхні еритроцитів. У зв'язку з цим за спектром відбитого сигналу після багаторазового детектування, фільтрації та перетворення отримуємо інтегральну характеристику капілярного кровотоку в заданій одиниці об'єму тканин, яка складається з середньої швидкості руху еритроцитів, показника капілярного гематокриту та кількості функціонуючих капілярів [8].

Ступінь судинних порушень залежить від тяжкості деструктивних змін, тривалості травми, сили агента та супутніх патологій. При вивченні показників лазерної допплерівської флоуметрії дослідниками встановлено зниження інтенсивності капілярного кровотоку в середньому на 30 \% від нормального рівня, що зумовлено запально-деструктивними процесами в пародонті $[9,10]$. Проблема попередження крайового пародонтиту та рецесії ясен після підготовки під незнімні конструкції, як і раніше, залишається актуальною. Недостатньо вивчено питання стану капілярного кровопостачання пародонта безпосередньо після ретракції, а також у найближчі терміни в людей із різними біотипами ясен.

(C) В.П. Неспрядько, С.С. Терехов, 2019 
Мета даного дослідження - оцінити вплив ретракції на мікроциркуляторне русло в тканинах крайового пародонта в пацієнтів із різними біотипами перед отриманням відбитка для незнімних конструкцій.

\section{Матеріал і методи}

Обстежено 34 пацієнти (22 жінки і 12 чоловіків). Об'єктом дослідження був репрезентативний контингент пацієнтів у період протезування незнімними конструкціями у фронтальній ділянці. Клінічне обстеження пацієнтів проводили у віковому інтервалі від 35 до 45 років. Окрім вікового діапазону, одним 3 основних критеріїв відбору пацієнтів була обов'язкова відсутність суб'єктивних проявів та органічних змін у структурі скронево-нижньощелепного суглоба, що підтверджувалось рентгенологічно.

Пацієнтів за схожих клінічних ситуацій розподілили на дві групи, різниця була тільки за типом ясен. До першої групи ввійшли пацієнти з товстим біотипом ясен, до другої - із тонким біотипом ясен. Усім пацієнтам виконували ретракцію ясенного краю. Перед проведенням даної процедури в паціснтів було клінічно визначено біотип за Х.П. Мюллером (2004). Глибину ясенної борозни виміряли за допомогою пародонтального зонда з інтервалом 0,25 мм i досліджували стан крайового пародонта за допомогою пародонтальних індексів. Здоров'я пародонта оцінювали за допомогою пародонтального індексу та індексу кровоточивості ясен (H.R. Muhlemann, 1981). У всіх пацієнтів вимірювали мікроциркуляцію в крайовому пародонті за допомогою лазерної допплерівської флоуметрії на апараті «Лакки-01» (НПП «Лазма», РФ) - лазерному аналізаторі швидкості поверхневого капілярного кровотоку, сполученому з персональним комп'ютером. Перед початком дослідження калібрували сигнал відповідно до інструкції заводавиробника. У апараті як випромінювач використовували гелій-неоновий лазер ГН-2П із довжиною хвилі 0,63 мкм. Лазерне випромінювання до тканини і прийом відбитого сигналу в приладах лазерної допплерівської флоуметрії здійснюються зазвичай за допомогою світлодіодного зонда, що складається з трьох світлодіодних волокон. Одне світлодіодне волокно використовується для передачі зондуючого випромінювання, а два інших є такими, що приймають, тобто відпрацьоване випромі- нювання доставляється до приладу для фотометрування й подальшої обробки.

Показники мікроциркуляції вимірювали протягом 1,0 хв. Обстеження проводили за однакових умов у положенні сидячи з фіксацією голови на підголівнику стоматологічного крісла в першій половині дня. Відразу після ретракції і зняття відбитка знову проводили дослідження. Потім повторювали його через 5-7 днів. Ретракційні процедури проводили в усіх пацієнтів одними й тими самими методами без урахування індивідуальних біотипів.

\section{Результати та їх обговорення}

За даними лазерних допплерівських флоуметрограм, у пацієнтів першої і другої груп відбувається погіршення мікроциркуляції у крайовому пародонті після виконання ретракції, причому в пацієнтів із тонким біотипом ці зміни були більш виражені, ніж у осіб із товстим біотипом ясен. Показник Kv (коефіцієнт варіації), що характеризує вазомоторну активність мікросудин, збільшився в 10 разів, а показник M, за яким досліджують мікроциркуляцію, знизився в 3 рази відносно вихідних значень. Отримані дані свідчать про більш виражену реакцію на вплив травматичного фактора.

У дослідженнях, проведених у термін 57 днів після ретракції, установлено, що відновлення показників мікроциркуляції в обох групах відбувається неоднаково. Зокрема, у пацієнтів із товстим біотипом ясен (перша група) лише у $3 \%(\mathrm{p}<0,05)$ показники не доходили до норми відносно початкових даних. У пацієнтів із тонким біотипом (друга група) відновлення показників спостерігалось усього у $30 \%$ досліджуваних ( $<<0,05)$, що пов'язано з більш вираженими змінами в тканинах крайового пародонта, а саме: із травмою зубоясенного прикріплення під час ретракції. Отримані дані підтверджують думки авторів $[4,5,7]$, що препарування й ретракції ясен при протезуванні незнімними протезами негативно впливають на стан тканин крайового пародонта, викликаючи непрогнозовану рецесію ясенного краю або хронічний протезний стоматит.

\section{Висновок}

Важлива роль в оцінюванні ефективності лікування відводиться стану мікроциркуляції в тканинах пародонта. Вивчено стан мікроциркуляції в пацієнтів із клінічно здоровим пародонтом до ретракції ясен, безпосередньо 
після неї та через 5-7 днів після процедури. Не тільки через ортопедичну конструкцію погіршується стан крайових ясен. Через щільне напруження й ретракцію ясен також знижується кровообіг у руслі судин, у такий спосіб зни- жується й якість ортопедичного лікування. Найбільш виражений вплив відчували пацієнти з тонким біотипом ясен, що пов' язано $з$ пошкодженням епітеліального прикріплення під час ретракції.

\section{Список літератури}

1. Ефанов О. И. Лазерная допплеровская флоуметрия в диагностике пародонтита / О. И. Ефанов, Ю. С. Суханова // Применение лазерной допплеровской флоуметрии в медицинской практике : материалы II Всерос. симпозиума. - М., 1998. - С. 44-45.

2. Жулев Е. Н. Клиника, диагностика и ортопедическое лечение заболеваний пародонта / Е. Н. Жулев. - Н. Новгород : НГМА, 2003. - 276 с.

3. Исимару A. Распространение и рассеяние волн в случайно-неоднородных средах : в 2 т. / А. Исимару. - М. : Мир, 1981. - Т. 1. - 1981. -285 с.

4. Кречина $E$. K. Динамика изменений капиллярного кровотока в тканях пародонта при его воспалительных заболеваниях / Е. К. Кречина // Применение лазерной допплеровской флоуметрии в медицинской практике : материалы II Всерос. симпозиума. - М., 1998. - С. 54-56.

5. Логинова Н. К. Микроциркуляция в тканях пародонта. Динамика функциональной гиперемии / Н. К. Логинова, Е. К. Кречина // Стоматология. - 1998. - Т. 77, № 1. - С. 25-27.

6. Физические основы метода лазерной допплеровской флоуметрии и его применение в неврологической практике / В. В. Сидоров, М. А. Ронкин, И. М. Максименко [и др.] // Биомедицинские технологии и радиоэлектроника. - 2003. - № 12. - С. 26-35.

7. Трезубов $B$. Н. Клиническая и микробиологическая картина протетических краевых пародонтитов / В. Н. Трезубов, О. Н. Аль-Хадж // Панорама ортопедической стоматологии. - 2002. - № 1. C. $44-46$.

8. Almond N. Laser Doppler flowmetry: theory and practice / N. Almond // Laser Doppler / [ed. by G. Belcaro, U. Hoffman, A. Bollinger, A. Nicolaides]. - London, Los Angeles, Nicosia : Med-Orion Publishing Company, 1994. - P. 17-31.

9. Braverman I. M. Correlation of laser Doppler wave patterns with underlying microvascular anatomy / I. M. Braverman, A. Keh, D. Goldminz // J. Investr. Dermatol. - 1990. - Vol. 95. - P. 283.

10. Shillinburg $H$. Fundamentals of tooth preparation for cast metal and porcelain restorations / H. Shillinburg, R. Jacobi, S. Brackett. - Chicago - London - Berlin - St-Paulo - Tokyo and Hong Kong : Quintessence publishing Co., Sec. Print, 1991. - 390 p.

\section{References}

1. Yefanov O.I., Sukhanova Yu.S. (1998). Lazernaia dopplerovskaia floumetriia v diahnostike parodontita [Laser Doppler flowmetry in the diagnosis of periodontitis]. Proceeding from Primeneniie lazernoi dopplerovskoi floumetrii v meditsinskoi praktike: materialy II Vserossiiskoho simpoziuma - The use of laser Doppler flowmetry in medical practice: Proceedings of the II All-Russian Symposium. (pp. 4445). Moscow [in Russian].

2. Zhulev Ye.N. (2003). Klinika, diahnostika i ortopedicheskoie lecheniie zabolevanii parodonta [Clinic, diagnosis and orthopedic treatment of periodontal diseases]. N. Novgorod: NGMA, 276 p. [in Russian].

3. Isimaru A. (1981). Rasprostraneniie i rasseianiie voln v sluchaino-neodnorodnykh sredakh [Wave propagation and scattering in randomly inhomogeneous media] (Vol. 1-2). Moscow: Mir, vol. 1, 285 p. [in Russian].

4. Krechina Ye.K. (1998). Dinamika izmenenii kapilliarnoho krovotoka v tkaniakh parodonta pri yeho vospalitelnykh zabolevaniiakh [The dynamics of changes in capillary blood flow in periodontal tissues with its inflammatory diseases]. Proceeding from Primeneniie lazernoi dopplerovskoi floumetrii $v$ meditsinskoi praktike: materialy II Vserossiiskoho simpoziuma - The use of laser Doppler flowmetry in medical practice: Proceedings of the II All-Russian Symposium. (pp. 54-56). Moscow [in Russian].

5. Lohinova N.K., Krechina Ye.K. (1998). Mikrotsirkuliatsiia v tkaniakh parodonta. Dinamika funktsionalnoi hiperemii [Microcirculation in periodontal tissues. Dynamics of functional hyperemia]. Stomatolohiia - Stomatology, vol. 77, № 1, pp. 25-27 [in Russian]. 
6. Sidorov V.V., Ronkin M.A., Maksimenko I.M., Shcherbanina V.Iu., Ukolov I.A. (2003). Fizicheskiie osnovy metoda lazernoi dopplerovskoi floumetrii i yeho primeneniie v nevrolohicheskoi praktike [Physical basis of the laser Doppler flowmetry method and its application in neurological practice]. Biomeditsinskiie tekhnolohii i radioelektronika - Biomedical Technologies and Radio Electronics, № 12, pp. 26-35 [in Russian].

7. Trezubov V.N., Al-Khadzh O.N. (2002). Klinicheskaia i mikrobiolohicheskaia kartina proteticheskikh kraievykh parodontitov [Clinical and microbiological picture of prosthetic marginal periodontitis]. Panorama ortopedicheskoi stomatolohii - Panorama of Orthopedic Dentistry, № 1, pp. 44-46 [in Russian].

8. Almond N. (1994). Laser Doppler flowmetry: theory and practice. Laser Doppler. G. Belcaro, U. Hoffman, A. Bollinger, A. Nicolaides (Ed.). (Pp. 17-31). London, Los Angeles, Nicosia: Med-Orion Publishing Company.

9. Braverman I.M., Keh A., Goldminz D. (1990). Correlation of laser Doppler wave patterns with underlying microvascular anatomy. J. Investr. Dermatol., vol. 95, pp. 283.

10. Shillinburg H., Jacobi R., Brackett S. (1991). Fundamentals of tooth preparation for cast metal and porcelain restorations. Chicago - London - Berlin - St-Paulo - Tokyo and Hong Kong: Quintessence publishing Co. Sec. Print, 390 p.

\section{В.П. Неспрядько, С.С. Терехов ВЛИЯНИЕ РЕТРАКЦИИ НА МИКРОЦИРКУЛЯТОРНОЕ РУСЛО В ТКАНЯХ КРАЕВОГО ПАРОДОНТА ПЕРЕД ПОЛУЧЕНИЕМ ОТТИСКА ДЛЯ НЕСЪЕМНЫХ КОНСТРУКЦИЙ}

В статье рассматривается влияние ретракции десен на микроциркуляторное русло в тканях пародонта у пациентов с различными биотипами десен. Отмечается взаимосвязь между силой травмирующего агента при ретракции десны и фенотипом краевого пародонта.

Ключевые слова: микроциркуляторное русло, ретракиия десны, несъемные конструкиии, оттиски, допплеровская флоуметрия.

\section{V.P. Nespradko, S.S. Terekhov}

\section{INFLUENCE OF RETRACTION ON THE MICROVASCULATURE IN THE MARGINAL PERIODONTIUM TISSUES BEFORE OBTAINING IMPRESSION FOR FIXED STRUCTURES}

The article discusses the effect of the retraction procedure on the microvasculature in the tissues of the regional periodontium in patients with various gum biotypes. The relationship between the strength of the traumatic agent during gum retraction and the phenotype of marginal periodontium is noted. Not only because of the orthopedic design, the condition of the marginal gum worsens. Due to the dense tension and gum retraction, blood circulation in the bloodstream also decreases, and the quality of orthopedic treatment is also reduced. The most pronounced effect was felt by patients with a thin gum biotype, which is associated with damage to the epithelial attachment during retraction.

Keywords: microvasculature, gum retraction, fixed structures, prints, Doppler flowmetry.

Надійшла 30.01.19

\section{Відомості про авторів}

Неспрядько Валерій Петрович - професор, доктор медичних наук, завідувач кафедри ортопедичної стоматології НМУ ім. О.О. Богомольця, Заслужений діяч науки і техніки України.

Адреса: 03680, м. Київ, вул. Зоологічна, 1, стоматологічний корпус, 2-4-й поверхи, Стоматологічний медичний центр НМУ ім. О.О. Богомольця.

Тел.: +38(044)454-49-64.

E-mail: brno.law@gmail.com.

ORCID: https://orcid.org/0000-0003-2912-1423.

Терехов Сергій Сергійович - аспірант кафедри ортопедичної стоматології НМУ ім. О.О. Богомольца (м. Київ).

Адреса: м. Бориспіль, вул. Лютнева, буд. 12, кв. 1.

Тел. +38(063)337-35-05.

E-mail:dr.terehov@gmail.com.

ORCID: https://orcid.org/0000-0002-4313-9497. 